\title{
Botswana in the Southern African Periphery : the Limits of Capitalist Transformation in a 'Labour Reserve'
}

\section{Jack Parson}

\section{Introduction}

Small weak countries bordering on larger economically powerful countries find their room for developmental manoeuvre constrained. They have markets too small for conventional industrialisation, often a distorted structure of production and few or no comparative advantages. While this does not prevent all autocentric and internally integrated growth it does provide some real, if not always obvious, limits to conventional economic and social transformation.

There is nothing particularly new in this (somewhat oversimplified) view, but too often the roots and complexity of these fundamental facts of life fail to find their way into the development policy-making process. The process of devising development strategy and attendant short-term programmes and plans tends to concentrate on what can be done on the assumption of existing conditions, however much lip-service is paid to structural constraints. The structure of planning in many developing countries, based as it is on immediate short-term projects, works with a given environment, and within the limits of existing opportunities.

There is nothing unusual in this. It is to some extent in the nature of planning within constraints of uncertain long-term financial, administrative and political resources and capacities. But it is worthwhile from time to time to take a longer, and broader, view of the development process by bringing to the fore the range of and relationships between basic, structural limits to long-term development for such countries. This article is an attempt to do this for Botswana, a land-locked small underdeveloped economy overshadowed and to some extent economically dominated by its powerful neighbour and regional magnet, the Republic of South Africa.

Before describing the case of Botswana it is necessary to indicate a framework for considering the 'limits' within which Botswana operates. The question of 'limits' here is two-fold. One area concerns the range of limits provided by the environment within which Botswana exists at the moment. This in turn resolves into questions about the position of Botswana with respect to multinational capital and Botswana's geopolitical and economic position in the Southern African periphery. Secondly, one has to evaluate the extent to which these limits are temporary phenomena or long-term structural blockages.

In considering these issues two kinds of policymaking strategies are involved. One is a strategy designed to manipulate existing factors to overcome temporary limits in a gradualist sense. The other strategy aims to transform the structure of the economy and society to remove deeply rooted disabilities.

The limits faced, both short- and long-term, impose themselves at different levils with different effects. Three levels, with related effects, may be identified. First, there are in-country or internal factors - the natural and human resource base, the structure of production, the distribution of power and the cumulative tendencies of the existing system of production and consumption. Second, there is, in Southern Africa, a regional level. Here the relevant considerations are the extent and type of regional domination exercised by the regional centre, South Africa, its attendant comparative advantages and the cumulative tendencies of the basis of domination. Third, on the more general geographic and economic levels, one has to look at the extent of hierarchical relations as relations of subordination (on a regional and country level) and at the cumulative tendencies of the world system.

This article examines the possibility of Botswana's autocentric development through a discussion of the limits to such a process. In doing so it views 'limits' in a very broad historical sense, at different levels, and concentrates on the long-term obstacles presented by the regional and world systems. It suggests that the 'limits' to Botswana's ability to generate an autocentric process of development arise from its constitution as a particular kind of dependent capitalist country, a significant component of which has been its geographical position on the periphery of South Africa - itself a capitalist formation in a system of such nations. This means that the roots of the 'limits' to Botswana's room for 
manoeuvre are to be found in its historical constitution and contemporary position.

These need to be highlighted and discussed. The short-term planning problem and the constraints implied have been dealt with in earlier work [Selwyn 1975]. This article begins with a consideration of Botswana's creation in the colonial period, followed by an examination of its performance in the post-colonial period. It then evaluates this performance in the context of the framework outlined above. It concludes with a brief indication of possible alternative strategies which focus more clearly on the limits described.

\section{The Labour Reserve Economy : Creation and Consequence}

\section{The early period}

The underlying structural impediment to Botswana's development is to be found in its original constitution as a 'labour reserve' in the colonial period. The declaration of British 'protection' in $1885-86$, the proximate cause of which was a geopolitical British fear of Afrikaner (Boer) and German expansionism [Sillery 1974; Dachs 1972], marked the beginning of a restructuring of economic and political relationships. This restructuring took internal and external forms.

Internally, territorial demarcation, taxation, and the restriction of opportunities to engage in capitalist enterprise created conditions for the emergence of labour as a commodity, as a wage earning population [Ettinger 1972; Gunderson 1970; Parson 1979; Parsons 1977; Schapera 1947]. The restructuring of internal political relations, primarily the superordinate position of British colonial administration, created and reproduced this social phenomenon [Sillery 1974; Bermingham 1978; Lord Hailey 1957].

The overall result was the creation of a "peasantariat' as the leading class. The peasantariat was characterised by continued subsistence agricultural production combined with the need to earn wages to satisfy its cash requirements [Parson 1979]. Socially the colonial state acted to maintain conditions for subsistence agriculture, for the reproduction of indigenous control (indirect rule), and the aggregation and supply of large numbers of unskilled labourers. The latter phenomenon required a rudimentary social infrastructure including a crude transportation system and little else in the way of educational and economic structures. Such conditions applied outside Bechuanaland in other portions of Southern Africa - most relevantly in Lesotho and Swaziland [Leys 1979; Fransman 1978].

Material British interests at the time were in South Africa's developing mining industry. This required large numbers of low-wage unskilled labourers [Legassick and LeClerq 1978]. The low-wage component of this requirement was met through the retention of communal subsistence agricultural activities in the Bechuanaland Protectorate together with migratory employment. Wages could then fall below the value of labour power because the subsistence needs and social infrastructure for the labourer's family were met in the Protectorate rather than in South Africa.

Thus, Bechuanaland became a 'labour reserve', supplying South African mines with large numbers of labourers and bearing the cost of social reproduction for that portion of the South African working class. By 1910 there were 2,891 'Bechuanaland Natives' employed in the 'Labour Districts' of South Africa, increasing to 4,323 in 1925. By 1943 nearly half of the men aged 15-44 were working outside Bechuanaland [Schapera 1947].

In these ways Bechuanaland became a dependent and capitalist economy. Its dependence on South Africa was nearly complete - reflected in its tax base, the market for its cattle, and its consumption of goods depending upon the maintenance of its position as a supplier of labour. It was capitalist because of the transformation of the peasantry into a capitalist working class, the peasantariat, although with its own distinctive features. And through this the ability to engage in an autocentric process of development was lost.

What is seen here are some of the main roots of the 'constraints' on development in present day Botswana. Colonial boundaries created a large country with a small population and few known natural resources. Its function as a reserve army of labour prevented the building of the social infrastructure needed even to consider the creation of productive capacity. It became part of the market for production in South Africa, not least through its economic integration in a customs union, its dependence on a railway owned in Rhodesia, and the use of South African currency and banking. Such economic subordination became a condition for the growth of South Africa. The strength of South African mining, and subsequently manufacturing, were reflected in the weaknesses of Bechuanaland. Bechuanaland's unattractiveness for industrial development reflected the attractiveness of the infrastructure, central location and other 
advantages of the developing capacity of South Africa.

Industrial capitalism in South Africa was not an isolated phenomenon; it had its own exogenous base. It was as a part of British Imperialism that much of this took place, although the actual point of production was in South Africa and there was an element of capital accumulation as South African accumulation. Thus international capital was involved in this process. The implications of this for the contemporary period are enormous. While the problems of internal development in Botswana arise most openly in terms of its relationship with its neighbour, it cannot be assumed that severing or weakening its ties of dependence on that territory will enable development to take place. There are, in addition, its relationships with capital in other parts of the world to consider.

\section{Dependency and change}

These relationships were not static in the sense that once established they remained unchanged in all respects. Although the structural base remained, the colonial period was one of change [Parson 1979]. This in part was brought about through the external nature of capitalism, but world depression and war had their effects too. The disintegration of formal Imperialism in the post-World War II period created conditions for political change in Bechuanaland. In addition, the colonial social structure, depending on an indigenous though subordinate governing class, itself underwent changes. There was, for example, a need for some education. And there was a cattle owning class largely coterminous with the indigenous power structure. These provided bases for demands for more indigenous control over the machinery of the state and a relaxation of restrictions on African economic activity. And there were changes in South Africa, notably at the political level with the victory of the Nationalist Party in 1958 and the creation of the system of apartheid.

These factors had two distinct and related effects. They combined to create conditions and an organisation to bring about an ending of colonial rule in 1966 and the creation of a politically independent Botswana. And they created a small but educated and articulate capitalist class which led the movement to independence. This organisation emerged as the Bechuanaland Democratic Party (BDP) in 1962. It was led by a cadre of cattle owners with 'traditional' standing along with an educated stratum of ex-teachers and civil servants.

The importance of this was two-fold. First, the articulation of peasantariat needs remained inco- herent. It was a capitalist, not a working class which led the anti-colonial struggle. This meant that the fundamental labour reserve nature of the economy was not challenged. Secondly, the post-colonial period would see an attempted capitalist transformation: the attempt to develop would be made within the confines of the pre-existing economic structure. It is therefore necessary to examine briefly the attempt at capitalist transformation in order to assess the persistent blockages to development in Botswana because of its peripheral and dependent position.

\section{The Post-colonial Period: Continuity and Change}

The post-colonial period was characterised by two associated and dominant trends. One was the achievement of dramatic economic growth. But, secondly, this growth was achieved through a diversification of Botswana's dependence. Economic growth was associated with a re-ordering of the dependent nature of the economy rather than through a change in its constitution as a dependent economy [Johns 1973; Parson 1979].

\section{Economic growth and the manipulation of ties of} dependence

The independence era witnessed substantial economic growth [Republic of Botswana 1977a]. Gross Domestic Product (GDP) increased from P32.9 mn in 1965 to P192 mn in 1973-74, at current prices - over 10 per cent per annum in real terms. All sectors of the economy grew, led by mining, quarrying and prospecting which grew from P0.2 mn in 1965 to Pl5.9 mn in 1973-74. Formal sector employment grew rapidly, reaching 47,804 in 1972 and 71,380 in 1976 , led by government employment.

Much of this growth reflected three factors. First, the output of the economy at independence was low. There were virtually no all-weather roads, no urbanisation, little formal employment and minimal investments in productive enterprise. A small increase appeared to be a quantum jump. This does not detract from the very substantial improvement in economic performance, but puts it into perspective.

Secondly, much of this growth was based on the attraction of significant bi-lateral and multi-lateral aid support from North America and Europe. To this extent growth was externally induced. About three-quarters of all government development expenditure from 1966-67 to 1980-81 was or was expected to be financed from external sources [Republic of Botswana 1977a]. Grants and loans on 
this scale were made possible by Botswana's position as an extremely poor country, its image as a worthy aid recipient in its efforts to build a multiracial society in contrast to South Africa, its desire to lessen its dependence on South Africa, its administrative ability to attract aid, and its capacity to use it efficiently [Jones 1977].

Thirdly, growth reflected the discovery of mineral deposits - copper/nickel and, more important, diamonds. This made the prospect of lending money to Botswana viable and attracted massive foreign investment, amounting to several times GDP. Lacking the finance, manpower and technology to undertake mineral extraction itself, the Botswana Government went into partnership with foreign capital in order to do so. This economic growth represented an attempt by the Botswana Government to manipulate its ties of dependency in its favour. It sought to decrease its dependence on South Africa by establishing a variety of economic and other contacts elsewhere. Rather than accept aid from South Africa, it negotiated with the World Bank, USAID, the UK, Scandanavia and elsewhere for grants and loans. Where possible it sought to import direct from outside South Africa. For expatriate manpower the Botswana Government recruited from outside the region, largely from the UK for contract civil servants.

Utilising these new ties, Botswana began the attempt to loosen the South African and Rhodesian stranglehold. It was hoped that new employment opportunities due to mining and manufacturing would decrease the need for labour migration. A new customs union agreement, more favourable to Botswana, was negotiated [Landell-Mills 1971]. In 1976 a central bank and national currency, the Pula, were created and the currency tied to the US Dollar rather than the South African Rand. Banks were required to incorporate locally rather than remain branches of South African banks. In 1974 the government gave a commitment to creating a national railway, buying out Rhodesia Railways, and in 1978 Botswana received its first consignment of rolling stock. The development of a substantial market for Botswana beef in the UK lessened dependence on the South African market. Moreover, the sale of copper/nickel matte and diamonds on the world market generated funds outside the Rand area.

Thus, through its strategic geopolitical position in Southern Africa, its exemplary moral position on race relations, its commitment to maintaining an open foreign investment policy, and its ability to use the inflow of resources, Botswana both achieved growth and began constructing a material position less integrated into South Africa. But this decreased dependence was far from constituting independence of South Africa.

\section{The continuities of post-colonial society}

This growth did not alter the fundamentally external base of the Botswana economy; nor did it mean a more equitable distribution of wealth and incomes internally. Indeed, the external dependency of the economy increased while wealth and income distribution improved little, if at all. By 1974-75 46 per cent of GDP (P203.9 mn) was in the form of exports, 51.5 per cent of which were virtually raw materials. In the same year imports of goods and services (P142.3 mn) amounted to nearly 70 per cent of GDP [Republic of Botswana $1977 \mathrm{~b}]$.

More importantly, the growth which occurred was very largely through foreign investments in specific extractive enterprises and in infrastructural investments by the state. Neither of these significantly affected the employment problem and neither generated a capacity for a self-sustaining process of development as an autonomous centre of growth. The share of manufacturing in GDP actually fell from 8.2 per cent in 1967-68 to 7.0 per cent in 1974-75. Manufacturing enterprises were small and tended to be in 'light' and import substituting branches. Total sales in 1975-76 amounted to P17.7 mn (of which P6.4 mn were exported); employment was only 2,564. Imports of intermediate goods amounted to P8.3 mn or 46.9 per cent of total sales. The value added of P7.3 mn was less than the value of imported intermediate goods [Parson 1979]. Much, therefore, of the increased demand due to greater GDP was met through increased imports rather than through local production.

Foreign-owned mines were highly capital intensive. In 1976 only 5,500 people were employed in the entire mining and quarrying sector. The mines employed extremely sophisticated technology beyond the means of Botswana to control, let alone develop. There were few backward or forward linkages.

Many of the problems here were compounded by the historic nature of a small economy dependent on manufacturing capacity and technology developed in South Africa. It thus represented the perpetuation of the existing vicious circle. Although growth was achieved, it was at the cost of a deepening involvement in extending ties of dependence. 
State expenditures were largely in infrastructure, and not in promoting directly productive activity. The bulk of state expenditures were on roads, urban development and education. While much of this was necessary, given the state of these facilities at independence, such expenditures did not directly stimulate integrated development, even in agriculture. Agriculture continued to be dominated by beef production and the export of the products, particularly to Europe. Here the problem was the development and maintenance of access to the European market.

Internally, a governing class developed consisting mainly of salaried state employees and a stratum of well-to-do cattle owners who, through their control of the state, received very heavy subsidies and other government aids. The majority of the population, the peasantariat, derived few benefits and little if any increased ability to engage in production. In 1974-75, 45 per cent of the rural population owned no cattle at all; they thus participated in beef production solely as labourers and their ability to plough using oxen was severely constrained [Republic of Botswana 1975a]. Productive opportunities for the majority remained as limited as they had been in the past. This created well-known problems in its wake, with the associated potential for social instability [Parson 1979; Lipton 1978].

Thus, there were significant structural continuities from the colonial into the post-colonial period. While the benefits derived from Botswana's international position improved considerably, the structural base from which these emanated changed not at all. The limits imposed on the direction and growth of the economy were geographically widened but their nature did not change.

In the post-colonial period, then, Botswana pursued a strategy of negotiation and autonomous action to reduce its direct dependence on South Africa. Through negotiation it achieved certain concessions in the customs union, negotiated firm quotas for beef sales and maintained its political identity. Independently it has sought and received capital grants, loans and expatriate manpower from sources other than South Africa. It created a monetary system and central bank, and committed itself to taking over the railway. Much of this was made possible because it had important mineral deposits which generated internal resources. This gave a material base to its negotiating position. Botswana achieved budgetary self-sufficiency in 1972 and has generated government revenue in excess of its recurrent requirements since then [Hermans 1974].
In addition to mining investments as a means of building a more solid production base, Botswana sought to generate an autonomous agricultural economy. Here the main thrust, as yet still gaining momentum, was the attempted capitalist transformation of the cattle industry [Parson 1979; Chambers and Feldman 1973; Republic of Botswana 1973, 1975b]. The old system of communal unfenced grazing land combined with private ownership of cattle and higher beef prices led to overstocking and the possibility of irreversible damage to the natural environment. The BDP governments' response was to enclose the land on the basis of individual and group leases. These could be used as security for loans and would be inheritable. Along with the creation of facilities for those dispossessed (and who would be available as a wage-labour force on the ranches) this would amount to the transformation of communal into private lease-hold land.

At the same time, to make the operation economically viable, expanded profitable markets were sought. This meant in particular the maintenance and, it was hoped, the expansion of Botswana's richest market, the European Economic Community. But this depended upon the EEC agreeing to rebate the import levy on Botswana beef, for if Botswana were subject to the duty the market would become only marginally profitable. So far the Community has been willing to grant such rebates only on an annual basis.

Relying on its negotiating skill and loan resources from the World Bank, among others, Botswana has begun to allocate areas for commercial ranches. This venture in capitalist transformation is one that did not depend directly upon Botswana's relations with South Africa. But while Botswana overcame an element of its dependence on South Africa, its strategy was one of engaging in a directly dependent relationship with the main centres of capitalism. Thus Botswana's dependence was not so much decreased as diversified.

\section{The Post-colonial Period : Capitalist Strate- gies of Development in the Labour Reserve Political Economy}

The key long-term assumption underlying development planning in Botswana has been that a small, dependent capitalist country, located in a region dominated by a larger capitalist country, can become an autonomous centre of growth through the creation and generalised spread of capitalist relations of production, and that this can be done through an association with the centres of world capitalism. Botswana's attempt to achieve an 
autonomous position has assumed in other words, that regional domination by South Africa is more or less unrelated to the domination of capital on a world-scale. Domination and its resulting obstacles are seen as regional problems.

Thus monopoly relations of production in mining, to the extent that these are not a specifically South African phenomenon, are not seen as creating new links of dependence, domination or deformation of the structure of production. They are seen as a means of increasing Botswana's ability to make internal decisions about the structure of production. Further, the expenditure of large sums of money, obtained externally, on a social infrastructure designed to stimulate capital intensive development is viewed as creating independence from South Africa. And the creation of a specifically large-scale capitalist cattle industry, with its market in Europe, is seen as the means of creating autonomy in relation to South Africa.

An evaluation of the post-colonial period based on this major assumption has a self-fulfilling quality. If these are the criteria, then it can be shown that a degree of autonomous growth has occurred. Although Botswana continued to depend on South Africa for much of its imports, and for transportation, it decreased its dependence in terms of monetary policy, revenue, manpower, and markets. Although the cumulative tendencies of domination have not been entirely broken, a stage of 'takeoff' may be reached, where Botswana develops a structure of production in which autonomous growth is generated outside its integration in a regional system. Although Botswana will have to 'live with' a limited market and natural resource endowment, the possibility of long-term autonomy is implied in the present trajectory.

If, however, one takes a wider and more comprehensive view, serious questions arise as to the structural position of the Botswana economy in Southern Africa and in the world. Two problems arise. First, has a plateau been reached (or will one be reached) in decreasing Botswana's dependence on South Africa? If Botswana remains a national entity, its limited market and natural resources will remain as more or less permanent restraints on industralisation in comparison with South Africa. it is highly unlikely, given the present configuration of production relations in the region, that Botswana will be able to develop manufacturing capacity. Moreover, the development which has taken place has not fundamentally affected the reproduction of a peasantariat dependent upon migrant labour. The creation of internal production opportunities has not stemmed the flow of labour abroad. Political stability and incomes in Botswana still depend upon this outlet. And the evidence appears to be for a declining demand for Botswana labour in South Africa [Lipton 1978], which will weaken Botswana's bargaining position in the South African labour market.

Secondly, what interpretation should be placed on Botswana's new relation to the centres of capitalism outside the region? Botswana's new 'autonomy' has meant creating an infrastructure, and social structure, facilitating the introduction of monopoly relations of production in mining and a capitalist transformation of cattle production. Roads, water supplies, electricity generation and other services were provided disproportionately for the construction of mining operations, and yield very marginal benefits otherwise. Moreover, mechanisms have been created to control wages, trade unions, and elements that might lead to 'instability' from the point of view of multinational capital. Botswana's 'autonomy' has been exercised to provide such services and conditions. Its integration into a world system is heightened by the fact that the transformation of cattle production is ultimately premised on maintaining Botswana's market in Europe; the development of capitalist relations in cattle production depends upon this.

Thus, underlying historical tendencies and the structural deformation of the economy as a labour reserve have changed little if at all. This is not to say that there has been no growth. The size of the surplus produced in Botswana has increased dramatically and a stratum of society has benefited from this. Botswana has improved its position in carving out a place in the world outside its relationship with South Africa. But the historically induced domination of Botswana by capital has been reproduced in all essential respects.

\section{Conclusion : Alternative Strategies}

Our evaluation cannot be left at this point. The inevitable, and legitimate, question poses itself what is the alternative? Just what can be done? Those who recognise the structural problems often fall back on such questions as a justification for pursuing the existing strategy.

This paper presents no detailed master blueprint. But that is not an admission of the impossibility of its construction. Until, however, there is a general sense that the end of the line has been reached, little concerted effort will be brought to bear on the question. Moreover, no detailed blueprint can be drawn up; this will emerge in the day-to-day struggle to achieve goals which can be specified at a 
general level. Nevertheless a start can be made, if only to suggest that there is an alternative.

First, there must be a change in the perception of what is being developed, and in whose interest. Social needs must be redefined in terms of the class which now has the greatest need and the least ability to produce, namely, the peasantariat. Development planning must start with their problems, and principally the absence of productive opportunities. And first and foremost there is the lack of such opportunities in agriculture, not as wage labour, but as part of a system which maximises the involvement of the peasantariat in agricultural production. Here an increased degree of self-sufficiency through peasantariat production would be a leading objective.

This would require a variety of planning reorientations. It would require a shift of resources away from capital intensive cattle production and toward smaller-scale more labour intensive crop production. This would involve a reorientation of research and project planning in water supplies toward smaller-scale irrigation. It would also require research into new crop varieties. Much could be learned by research on existing 'traditional' food crops, their suitability for developing hybrid varieties and improved methods of cultivation. A shift would be required away from the production of cattle for meat, and toward their use as productive assets in the form of draught power in arable production. This, in turn, would yield an impetus for a substantial effort in developing new or 'alternative' technologies, building on existing peasantariat technology.

New rural peasantariat-based educational, administrative and political structures would be needed, fully integrated both with the rural areas and the new planning apparatus. And a general decentralisation of responsibility for project planning and implementation would be required. Some form of block grants to rural communities with back-up support in logistics and financing could allow the peasantariat to control the direction of planning.

This would significantly affect policies and strategies regarding mineral extraction. The need for revenue from the mines would be set against the consequences of that extraction for the peasantariat. The questions of whether to mine, how rapidly to mine, and the extent of structuring social relations in order to mine could be looked at through peasantariat eyes.

This is one alternative. It is not a magic solution for serious problems have to be tackled. The struc- turing of the power of the peasantariat, the relationship of technical expertise to peasantariat planning, and the position of the bureaucracy, are three problem areas. Moreover, such an alternative is unlikely to be adopted given the existing distribution of class power in Botswana. Indeed, some of these suggestions are contained in existing documents; without exception the 'equity' recommendations have not found their way into planning [Lipton 1978; Chambers and Feldman 1973]. The peasantariat does not control the state and there is little likelihood that it will in the near future. The existing power holders - the large cattle owners and the bureaucrats - are unlikely to abandon their position.

However, given the present course, these issues will have to be faced at some point. It is, therefore, time to begin thinking seriously about them. This is not least the case given the possibility of significant change in South Africa. In this dicussion the confining and long-term 'limits' to development can be faced most squarely.

\section{References}

Bermingham, Jack, 1978, 'Shaping Colonial Rule: The Bechuanaland Protectorate African Advisory Council', African Studies Association (USA), Conference

Chambers, R. and D. Feldman, 1973, Report on Rural Development, Government Printer, Gaborone

Dachs, Anthony, 1972, 'Missionary Imperialism - the case of Bechuanaland', Journal of African History, vol XIII

Ettinger, Stephen, 1972, 'South Africa's weight restrictions of cattle exports from Bechuanaland, 1924-41', Botswana Notes and Records, vol 4

Fransman, Martin, 1978, The State and Development in Swaziland, 1960-77, DPhil Thesis, University of Sussex

Gunderson, G. L., 1970, Nation Building and the Administrative State: the Case of Botswana, PhD Thesis, University of California, Berkeley

Hailey, Lord, 1957, An African Survey Revised, Oxford University Press, London

Hermans, Quil, 1974, 'A review of Botswana's financial history, 1900-73', Botswana Notes and Records, vol 6 
Johns, Sheridan, 1973, 'Botswana's strategy for development: an assessment of dependence in the Southern African context', Journal of Commonwealth Political Studies, vol XI

Jones, David, 1977, Aid and Development in Southern Africa, Croom Helm, London

Landell-Mills, P. M., 1971, 'The 1969 Southern African Customs Union Agreement', Journal of Modern African Studies, vol 9

Legassick, Martin and Francine LeClerq, 1978, 'The Origins and Nature of the Migrant Labour System in Southern Africa', ECA Conference on Migratory Labour in South Africa, Lusaka

Leys, Roger, 1979, 'Lesotho: non-development or underdevelopment. Towards an analysis of the political economy of the labour reserve', in T. M. Shaw and K. A. Heard (eds), The Politics of Africa: Dependence and Development, Longman, London

Lipton, Michael, 1978, Employment and Labour Use in Botswana, vol 1, Government Printer, Gaborone

Parson, Jack, 1979, The Political Economy of Botswana: a Case in the Study of Politics and Social Change in Post-Colonial Societies, DPhil Thesis, University of Sussex
Parsons, Neil, 1977, 'The economic history of Khama's country in Botswana, 1844-93', in R. Palmer and N. Parsons (eds), The Roots of Rural Poverty in Central and Southern Africa, Heinemann, London

Republic of Botswana, 1973, National Policy for Rural Development: the Government's Decisions on the Report on Rural Development by Dr R. Chambers and D. Feldman, Government Printer, Gaborone

- , 1975a, Rural Income Distribution Survey in Botswana 1974-75, Government Printer, Gaborone

- , 1975b, National Policy on Tribal Grazing Land, Government Printer, Gaborone

- 1977a, National Development Plan 197681. Government Printer, Gaborone

-, 1977b, Statistical Bulletin March 1977. Government Printer, Gaborone

Schapera, Isaac, 1947, Migrant Labour and Tribal Life: a Study of Conditions in the Bechuanaland Protectorate, Oxford University Press, London

Selwyn, Percy, 1975, Industries in the Southern African Periphery, Croom Helm, London

Sillery, Anthony, 1974, Botswana: a Short Political History, Methuen \& Co, London 